\title{
Penerapan Teknik Clustering Sebagai Strategi Pemasaran pada Penjualan Buku Di Tokopedia dan Shopee
}

\author{
Wiga Maulana Baihaqi ${ }^{1}$, Kuat Indartono², Syifaul Banat ${ }^{3}$ \\ ${ }^{1}$ Program Studi Teknologi Informasi Universitas Amikom Purwokerto \\ e-mail: wiga@amikompurwokerto.ac.id \\ ${ }^{2}$ Program Studi Teknik Informatika Universitas Amikom Purwokerto \\ e-mail: indartono@amikompurwokerto.ac.id \\ ${ }^{3}$ Program Studi Sistem Informasi Universitas Amikom Purwokerto \\ e-mail: syifaulbanat@gmail.com
}

\begin{abstract}
Cara Sitasi: Baihaqi, W. M., Indartono, K., \& Banat, S. (2019). Penerapan Teknik Clustering Sebagai Strategi Pemasaran pada Penjualan Buku Di Tokopedia dan Shopee. Paradigma - Jurnal Komputer dan Informatika, 21(2), 243-248. doi:10.31294/p.v21i2.6149
\end{abstract}

\begin{abstract}
Pustaka Aysha is one of the online bookstores in Shopee and Tokopedia. Shopee and Tokopedia are online shopping sites that are top ranked in Indonesia. The amount of competition that exists between stores so that requires a marketing strategy. This research uses clustering techniques in data mining marketing strategies. Clustereing is one technique in data mining to find data sets that have similarities with other data or data dissimilarity with others. The clustering process is carried out using $k$-means and k-medoids on the sales transaction data of the Pustaka Aysha bookstore in Shopee and Tokopedia on March 2019 and consists of each of the 488 data divided into 3 clusters namely the first cluster for the most product in demand, the second cluster for products that are quite popular and the third cluster for products that are of little interest. Both of these algorithms will be clustered evaluation to find out which algorithm has better performance in this research, the evaluation process is carried out using davies bouldin index to maximize inter cluster distance and minimize intra cluster distance, so the results obtained that the $k$-medoids algorithm have performance better than $k$ means.
\end{abstract}

Keywords: marketing strategy, clustering, k-means, $k$-medoids, davies bouldin index

\section{PENDAHULUAN}

Bisnis e-commerce mengalami perkembangan sangat pesat. Kemudahan transaksi yang didukung oleh sosial media menjadi salah satu berkembangnya toko online di Indonesia. Data statistik dari $e$ marketer, sebuah perusahaan yang bergerak dibidang statistik menunjukan bahwa pada tahun 2018 jumlah pengguna aktif smartphone di Indonesia lebih dari 100 juta orang dan akan terus berkembang pesat hingga tahun 2019 (Rahmayani, 2015).

Laporan dari e-marketer menyatakan bahwa akan terdapat dua miliar pengguna smartphone aktif di seluruh dunia pada tahun 2016. Dan Indonesia merupakan salah satu Negara yang mempunyai pertumbuhan terbesar, di bawah China dan India. Tiga Negara tersebut secara kolektif akan menambah lebih dari 400 juta pengguna smartphone baru dari 2014 hingga 2018 (Millward, 2014).

Peningkatan jumlah pengguna smartphone mengakibatkan meningkatnya pengguna media sosial. Berdasarkan hasil riset Wearesosial Hootsuite yang dirilis Januari 2019 pengguna media sosial di Indonesia mencapai 150 juta atau sebesar $56 \%$ dari total populasi. Jumlah tersebut naik $20 \%$ dari survei sebelumnya. Sementara pengguna media sosial mobile (gadget) mencapai 130 juta atau sekitar $48 \%$ dari populasi (Databoks, 2019).

Meningkatnya pengguna media sosial menjadi sebuah peluang menarik bagi para enterpreneur di Indonesia untuk memanfaatkannya menjadi sebuah bisnis online yang menguntungkan. Salah satu bisnis di media sosial adalah bisnis online buku. Pustaka Aysha merupakan salah satu toko buku online khususnya buku agama yang berdomisili di Purwokerto. Pustaka Aysha adalah satu dari sekian banyak toko yang memasarkan produknya melalui basis internet. Pustaka Aysha saat ini menggunakan beberapa media sosial untuk menunjang penjualannya, antara lain Shopee dan Tokopedia. Pustaka Aysha bergabung dengan Shopee sudah sekitar 2 tahun, berbeda dengan Tokopedia yang baru 1 tahun bergabung.

Banyaknya persaingan yang ada antar toko buku sehingga membutuhkan strategi pemasaran. Srategi 
pemasaran adalah pola pikir pemasaran yang akan digunakan untuk mencapai tujuan pemasarannya. Strategi pemasaran diantaranya berisi strategi spesifik untuk target pasar, penetapan posisi, bauran pemasaran dan besarnya pengeluaran pemasaran (Philip \& Amstrong, 2012).

Saat ini strategi pemasaran yang dilakukan oleh toko buku online Pustaka Aysha adalah dengan cara riset pasar, yaitu dengan mencari tahu mengenai produk buku agama yang terjual di toko buku online lainnya sehingga kurang efektif. Selain itu penentuan stok produk yang dilakukan hanya dengan melihat stok produk yang ada pada rak buku, sehingga seringkali terjadi kekurangan atau bahkan kelebihan dalam penentuan stok produk karena tidak berdasarkan minat konsumen. Adapun permasalahan lainnya seperti penjualan yang terjadi antara Shopee dan Tokopedia mengalami perbandingan yang jauh yaitu tingkat penjualan di Shopee sebesar 18,3\%, sedangkan di Tokopedia $0,81 \%$ tingkat penjualan.

Permasalahan yang terjadi pada toko buku online Pustaka Aysha memerlukan strategi pemasaran yang lebih efektif dan perlu adanya identifikasi untuk mengetahui factor-faktor apa saja yang menyebabkan fenomena pada penjualan yang berbanding jauh terjadi antara Shopee dan Tokopedia. Terjadinya persaingan antara Shopee dan Tokopedia yang dimana Shopee menduduki peringkat pertama di AppStore dan PlayStore yang saat ini terjadi peningkatan tehadap pengguna Smartphone dan internet. Hal ini yang menjadi faktor penyebab terhadap penjualan buku di Shopee dan Tokopedia yang bebanding jauh.

Berbagai penelitian yang terkait dengan penentuan strategi pemasaran pada produk sudah pernah dilakukan dengan berbagai metode. Seperti yang dilakukan oleh (Setiawan, 2018) dengan judul Pemanfaatan Metode K-Means Dalam Penentuan Persediaan Barang, pada penelitian tersebut peneliti menggunakan metode $k$-means untuk mengolah dataset transaksi penjualan produk pasta pada Gia Restaurant Jakarta. Data yang digunakan dari bulan Januari sampai Desember 2017. Hasil yang didapat dari penelitian ini menghasilkan 2 cluster dengan cluster pertama terdiri dari 15 data yang merupakan kelompok produk untuk jumlah sedikit, cluster kedua terdiri dari 6 data yang merupakan kelompok produk untuk jumlah banyak.

Penelitian lain dilakukan oleh (Fauzansyah, 2017) dengan judul Implemetasi Algoritma K-Means Clustering untuk Menentukan Arketipe Pembelian Suku Cadang dan Asesoris Komputer (Studi Kasus: Toko Laksamana Komputer Dumai), pada penelitian tersebut peneliti menggunakan metode $K$-Means untuk mengolah dataset transaksi penjualan pada toko tersebut. Hasil dari penelitian ini menghasilkan 3 cluster, pada cluster 2 dan 3 yang sering diminati komsumen.

Adapun penelitian lainnya oleh (Ramadhani \& Ak, 2017) dengan judul Evaluasi $K$-Means dan $K$ Medoids pada Dataset Kecil. Pada penelitian ini menggunakan metode $k$-means dan $k$-medoids untuk mengolah dataset yang berukuran kecil yaitu Iris dan Wine. Terdapat 4 atribut dan 150 data pada dataset Iris, sedangkan dataset Wine terdiri dari 13 atribut dan 178 data. Kedua algoritma tersebut kemudian dibandingkan dengan evaluasi clustering menggunakan DBI, sehingga menghasilkan algoritma k-means lebih baik dibandingkan dengan $k$-medoids.

Berdasarkan penelitian sebelumnya, maka dalam penelitian ini penulis dapat menentukan strategi pemasaran yang tepat, yaitu dengan melakukan promosi pada produk dan penentuan stok produk berdasarkan peminatan konsumen, sehingga perlu dilakukan pengolahan data transaksi penjualan. Data penjualan pada toko buku online Pustaka Aysha yang ada di Shopee dan Tokopedia akan diolah untuk mengetahui pola dari data, sehingga dapat diambil informasi dari data tersebut. Pengolahan data yang dilakukan biasa dikenal dengan istilah data mining. Salah satu metode analisa data mining yang digunakan adalah clustering. Clustering yang dilakukan pada penelitian ini menggunakan metode $k$-means dan $k$-medoids, sehingga akan ditemukan informasi yang dapat digunakan untuk penentuan strategi pemasaran produk yang tepat. Software yang digunakan sebagai pendukung pengolahan data adalah RapidMiner. Hasil dari kedua metode tersebut kemudian akan dibandingkan dengan melakukan evaluasi clustering untuk mengetahui mana hasil yang lebih akurat dalam penelitian ini.

\section{METODOLOGI PENELITIAN}

\section{Bahan}

Bahan yang digunakan dalam penelitian ini merupakan data transaksi penjualan pada toko buku online Pustaka Aysha di Shopee dan Tokopedia pada bulan Maret tahun 2019 yang memiliki 10 atribut yaitu: kategori, kode produk, jumlah transaksi, disukai, dan penilaian 1 sampai dengan penilaian 5. Terdiri dari 444 data dari masing-masing toko.

\section{Pengolahan Data Awal}

Data yang sudah dikumpulkan akan diolah dengan beberapa tahap sehingga menjadi sebuah dataset yang akan diimplementasikan menggunakan metode data mining. Dataset transaksi penjualan digunakan dalam tahap pengolahan data. Pada tahap ini ditentukan atribut yang akan digunakan pada tahap clustering, dari 10 atribut yang didapatkan pada proses pengumpulan data kemudian diseleksi hanya menjadi 8 atribut, atribut kategori dan kode produk tidak dilibatkan dalam proses clustering, karena atribut tersebut tidak berpengaruh dalam tahap pengelompokan data. Pada tahap ini juga dilakukan penyamaan data antara produk shopee dan data tokopedia, buku yang tidak terjual pada kedua toko online tersebut tidak digunakan. Tahap terakhir yaitu 
menentukan jumlah kelompok yang akan dibentuk, hasil yang diharapkan pada penelitian ini yaitu akan terbentuk tiga cluster, cluster 1, cluster 2, dan cluster 3 . Cluster 1 didefinisikan sebagai produk yang harus diperhatikan penyedian stok dengan jumlah paling banyak, sedangkan cluster 2 dan 3 merupakan produk dengan penyedian stok dibawah cluster 1 .

\section{Penerapan Algoritme}

Pada tahap ini melakukan clustering pada dataset yang telah di preprocessing. Proses pengklasteran akan dilakukan dengan menggunakan metode $k$ means dan k-medoids. Dimulai dari memasukan jumlah data yang dibutuhkan dan jumlah cluster yang telah ditentukan. Selanjutnya dilakukan proses dari seluruh perhitungan $k$-means dan $k$ medoids. Hasil cluster akan ditampilkan pada akhir proses ketika proses perhitungan telah selesai.

Menurut Wu dan Kumar dalam (Prasetyo, 2014) algoritma $k$-means merupakan algoritma pengelompokan iterative yang melakukan partisi dataset ke dalam sejumlah $K$ cluster (kelompok) yang sudah ditetapkan di awal. K-Means merupakan algoritma clustering yang melakukan pengelompokan objek berdasarkan jarak terdekat tiap cluster dengan pusat klaster ke dalam kelompok yang memiliki kemiripan satu sama lain (Ramadhani \& Ak, 2017). Tahapan-tahapan dari algoritma $k$-means adalah:

a. Menentukan centroid awal dengan memilih sejumlah $k$ objek.

b. Setiap objek yang bukan centroid dimasukan ke cluster berdasarkan jarak terdekat.

c. Hitung kembali centroid berdasarkan rata-rata dari objek yang ada di dalam cluster.

d. Ulangi langkah ke 2 dan 3 hingga tidak ada perubahan pada cluster.

Sedangkan $K$-Medoids menggunakan objek representatif dengan secara acak k objek sebagai titik acuan (medoid), bukan mengambil nilai ratarata dari objek dalam setiap cluster. Algoritma mengambil parameter input $k$, jumlah cluster yang akan dipartisi di antara satu setdata objek (Ramadhani \& Ak, 2017). Tahapan-tahapan dari

$k$-medoids adalah:

a. Secara acak pilih $k$ objek pada sekumpulan data objek sebagai medoid.

b. Setiap objek yang bukan medoid dimasukan ke dalam cluster berdasarkan jarak terdekat.

c. Perbarui medoid dengan memilih secara acak objek non medoid.

d. Hitung total cost $S$, dari pertukaran medoid.

e. Jika $S<0$ maka tukar objek secara acak untuk membentuk sekumpulan $k$ objek baru sebagai medoid.

f. Ulangi langkah ke 3 sampai 5 hingga tidak ada perubahan pada.

Pada penelitian ini untuk mengukur kedekatan jarak antar data baik pada algoritme K-means maupun K-Medoids menggunakan pengukuran jarak Euclidean Distance. Persamaan 1 menunjukkan persamaan untuk mengukur jarak antar data menggunakan Eclidean Distance.

$D(x, y)=\sqrt{\sum_{k=1}^{n}\left(x_{i}-y_{i}\right)^{2}}$

Keterangan:

$\mathrm{D}(\mathrm{x}, \mathrm{y})=$ Jarak data $\mathrm{x}$ dan $\mathrm{y}$

$\mathrm{x}_{\mathrm{i}}=$ data $\mathrm{x}$ ke $\mathrm{i}$

$\mathrm{y}_{\mathrm{i}}=$ data $\mathrm{y}$ ke $\mathrm{i}$

$\mathrm{n}=$ jumlah data

\section{Evaluasi Clustering}

Dalam tahap ini dilakukan evaluasi performa metode penelitian yang telah digunakan dengan melihat hasil akurasi. Tahap evaluasi clustering dalam penelitian ini menggunakan metode Davies Bouldin Index (DBI). Davies Bouldin Index diperkenalkan oleh David L. Davies dan Donald W. Bouldin (1979) dalam (Prasetyo, 2014) yang digunakan untuk mengevaluasi cluster. DBI salah satu metode validitas internal yang akan dilakukan seberapa baik clustering sudah dilakukan dengan menghitung kuantitas dan fitur turunan dari dataset.

Davies Bouldin Index didasarkan pada kesamaan dari ukuran cluster yang berdasarkan pada penyebaran cluster dan ketidaksamaan ukuran cluster. Pendekatan ini adalah untuk memaksimalkan jarak inter cluster dan meminimalkan jarak intra cluster yang di dapat pada persamaan 2, 3, 4 dan 5 .

$S i=\frac{1}{|C i|} \sum_{x \in C i}\{\|x-z i\|\}$

Dimana $C_{i}$ sebagai banyaknya titik yang masuk ke dalam cluster $i, x$ adalah data, dan $Z_{i}$ centroid dari cluster $i$. sedangkan jarak antara cluster didefinisikan pada persamaan 3:

$d_{i j}=\|z i-z j\|$

Dimana zi centroid dari cluster $i$ dan zj centroid dari cluster $j$. Perhitungan jarak $d_{i j}$ dapat menggunakan Euclidean. Selanjutnya mendefinisikan $R_{i}$, qt untuk cluster $C i$ pada persamaan 4:

$R i, q t={ }_{j j \neq i}^{\operatorname{Max}}\left\{\frac{s_{i, q}+s_{j, q}}{d_{i j, t}}\right\}$

Davies-Bouldin Index didefinisikan pada 
persamaan 5:

$$
D B=\frac{1}{K} \sum_{i=1}^{k} R i, q t
$$

\section{HASIL DAN PEMBAHASAN}

Pada penelitian ini menggunakan aplikasi RapidMiner Studio untuk menyelesaikan proses pengelompokan data penjualan buku di Shopee dan Tokopedia. Tabel 1 dan 2 menujukkan data yang akan digunakan pada proses pengelompokan menggunakan algoritme KMeans dan K-Medoids, Tabel 1 merupakan data penjualan buku di platform Shopee, sedangkan Table 2 merupakan data penjualan buku di platform Tokopedia.

Tabel 1. Data Shopee

\begin{tabular}{ccccccc}
\hline $\begin{array}{c}\text { Jml } \\
\text { Transa } \\
\text { ksi }\end{array}$ & $\begin{array}{c}\text { Dis } \\
\text { uka } \\
\text { i }\end{array}$ & $\begin{array}{c}\text { Penil } \\
\text { aian } \\
1\end{array}$ & $\begin{array}{c}\text { Penil } \\
\text { aian } \\
2\end{array}$ & $\begin{array}{c}\text { Penil } \\
\text { aian } \\
3\end{array}$ & $\begin{array}{c}\text { Penil } \\
\text { aian } \\
4\end{array}$ & $\begin{array}{c}\text { Penil } \\
\text { aian }\end{array}$ \\
\hline 3 & 99 & 0 & 0 & 0 & 1 & 24 \\
12 & 64 & 0 & 1 & 0 & 2 & 66 \\
4 & 51 & 0 & 0 & 1 & 2 & 38 \\
3 & 77 & 0 & 0 & 0 & 5 & 26 \\
2 & 56 & 0 & 0 & 0 & 4 & 25 \\
$\ldots$ & $\ldots$ & $\ldots$ & $\ldots$. & $\ldots$. & $\ldots$. & $\ldots .$. \\
2 & 2 & 0 & 0 & 0 & 0 & 1 \\
68 & 54 & 0 & 0 & 1 & 4 & 34 \\
0 & 0 & 0 & 0 & 0 & 0 & 1 \\
14 & 0 & 0 & 0 & 2 & 4 & 0 \\
\hline
\end{tabular}

Tabel 2. Data Tokopedia

\begin{tabular}{ccccccc}
\hline $\begin{array}{c}\text { Jml } \\
\text { Transa } \\
\text { ksi }\end{array}$ & $\begin{array}{c}\text { Dis } \\
\text { uka } \\
\text { i }\end{array}$ & $\begin{array}{c}\text { Penil } \\
\text { aian } \\
1\end{array}$ & $\begin{array}{c}\text { Penil } \\
\text { aian } \\
2\end{array}$ & $\begin{array}{c}\text { Penil } \\
\text { aian } \\
3\end{array}$ & $\begin{array}{c}\text { Penil } \\
\text { aian } \\
4\end{array}$ & $\begin{array}{c}\text { Penil } \\
\text { aian }\end{array}$ \\
\hline 1 & 20 & 0 & 0 & 0 & 0 & 5 \\
0 & 0 & 0 & 0 & 0 & 0 & 0 \\
0 & 1 & 0 & 0 & 0 & 0 & 0 \\
0 & 1 & 0 & 0 & 0 & 0 & 0 \\
0 & 1 & 0 & 0 & 0 & 0 & 0 \\
$\ldots$ & $\ldots$ & $\ldots$ & $\ldots \ldots$. & $\ldots .$. & $\ldots .$. & $\ldots \ldots$. \\
0 & 1 & 0 & 0 & 0 & 0 & 0 \\
0 & 1 & 0 & 0 & 0 & 0 & 0 \\
0 & 1 & 0 & 0 & 0 & 0 & 0 \\
0 & 1 & 0 & 0 & 0 & 0 & 0 \\
\hline
\end{tabular}

Data pada Tabel 1 dan 2, per baris mewakili masingmasong data transaksi buku. Setelah data transaksi dari Shopee dan Tokopedia siap untuk diolah, maka data tersebut diimport ke dalam rapidminer menggunakan operator ReadExcel. Gambar 1 menunjukkan penerapan algoritma K-Means dan KMedoids untuk mengelompokan data dengan aplikasi
RapidMiner.

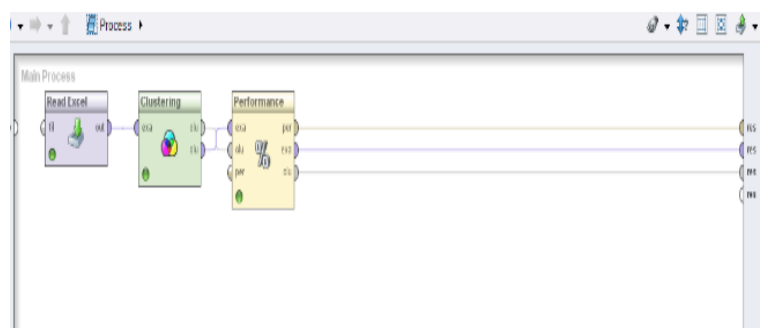

Gambar 1. Proses Clustering dengan RapidMiner

Data yang sudah diimportkan ke RapidMiner kemudian dihubungkan dengan operator Clustering, pada tahap ini harus menentukan algoritme yang akan digunakan, yaitu algoritme K-Means dan K-Medoids. Langkah terakhir yaitu menghubungkan operator clustering dengan operator Performance, operator performance digunakan untuk mengevaluasi hasil pengelompokan data yang dilakukan menggunakan algoritme K-Means dan K-Medoids. Davies-Bouldin Index dipilih pada operator performance yang digunakan.

Hasil dari proses clustering dataset di Shopee dengan menggunakan metode $k$-means diperoleh grafik seperti yang ditunjukkan pada Gambar 2 . Grafik pada Gambar 2 menunjukkan bahwa masingmasing cluster memiliki hasil yang berbeda yaitu Cluster pertama memiliki nilai sebesar $8,2 \%$ dari total rata-rata semua atribut yang terdiri dari 38 data, Cluster kedua memiliki nilai sebesar 1,3\% dari total rata-rata semua atribut yang terdiri dari 389 data, Cluster ketiga memiliki nilai sebesar 20,5\% dari total rata-rata semua atribut yan terdiri dari 17 data.

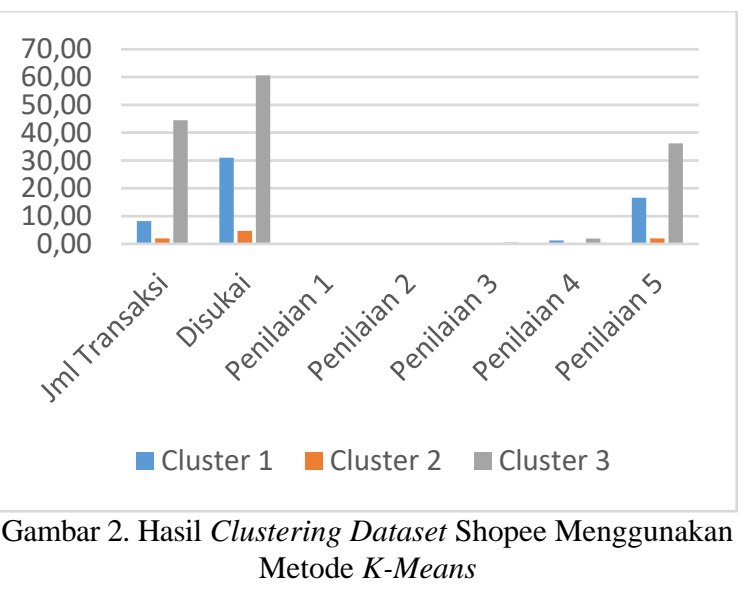

Berdasarkan hasil dari masing-masing cluster, sehingga dapat disimpulkan bahwa cluster pertama merupakan produk yang cukup diminati, sehingga persediaan stok dengan jumlah sedang, cluster kedua merupakan produk yang sedikit diminati, sehingga persediaan stok dengan jumlah sedikit, cluster ketiga merupakan produk yang paling diminati, sehingga pesediaan stok dengan jumlah banyak. Sedangkan 
hasil clustering dataset Shopee menggunakan metode $k$-medoids diperoleh grafik seperti ditunjukkan pada Gambar 3.

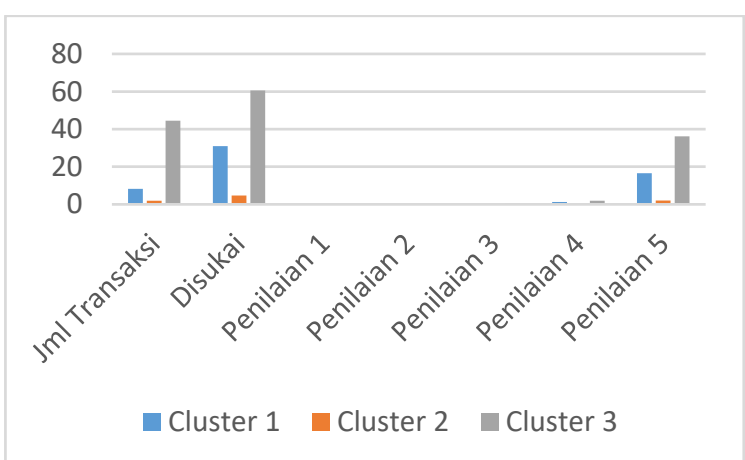

Gambar 3. Hasil Clustering Dataset Shopee Menggunakan Metode $K$-Medoids

Hasil grafik pada Gambar 3 menunjukkan bahwa cluster pertama memiliki nilai sebesar $3.2 \%$ dari total rata-rata semua atribut yang terdiri dari 31 data, cluster kedua memiliki nilai sebesar 1,7\% dari total rata-rata semua atribut yang terdiri dari 396 data, cluster ketiga memiliki nilai sebesar $16,6 \%$ dari total rata-rata semua atribut yan terdiri dari 17 data.

Berdasarkan hasil dari masing-masing cluster, sehingga dapat disimpulkan bahwa cluster pertama merupakan produk yang cukup diminati, sehingga persediaan stok dengan jumlah sedang, Cluster kedua merupakan produk yang sedikit diminati, sehingga persediaan stok dengan jumlah sedikit, cluster ketiga merupakan produk yang paling diminati, sehingga pesediaan stok dengan jumlah banyak Hasil dari proses clustering dataset di Tokopedia dengan menggunakan metode $k$-means diperoleh grafik seperti yang ditunjukkan pada Gambar 4.

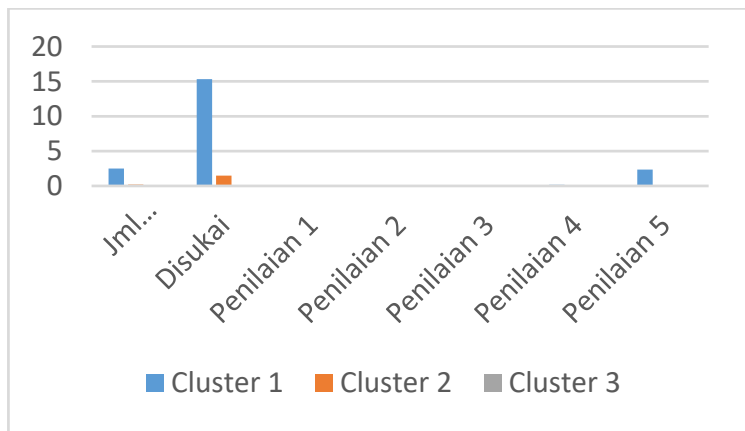

Gambar 4. Hasil Clustering Dataset Tokopedia Menggunakan Metode $K$-Means

Grafik pada Gambar 4 menunjukkan bahwa cluster pertama memiliki nilai sebesar $3 \%$ dari total ratarata semua atribut yang terdiri dari 6 data, Cluster kedua memiliki nilai sebesar $0,3 \%$ dari total ratarata semua atribut yang terdiri dari 176 data, cluster ketiga memiliki nilai sebesar $0,01 \%$ dari total ratarata semua atribut yan terdiri dari 262 data.
Berdasarkan hasil dari masing-masing cluster, sehingga dapat disimpulkan bahwa cluster pertama merupakan produk yang paling diminati, sehingga persediaan stok dengan jumlah banyak, cluster kedua merupakan produk yang cukup diminati, sehingga persediaan stok dengan jumlah sedang, cluster ketiga merupakan produk yang sedikit diminati, sehingga pesediaan stok dengan jumlah sedikit. Sedangkan hasil clustering dataset Tokopedia menggunakan metode $k$-medoids diperoleh grafik seperti ditunjukkan pada Gambar 5.

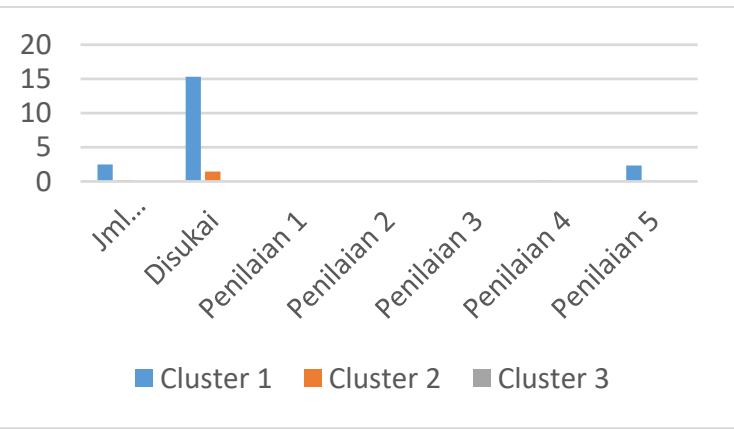

Gambar 5. Hasil Clustering Dataset Tokopedia Menggunakan Metode $\mathrm{K}$-Medoids

Hasil grafik pada Gambar 5 menunjukkan bahwa cluster pertama memiliki nilai sebesar $0,0 \%$ dari total rata-rata semua atribut yang terdiri dari 285 data, cluster kedua memiliki nilai sebesar 1,2\% dari total rata-rata semua atribut yang terdiri dari 26 data, cluster ketiga memiliki nilai sebesar $0,2 \%$ dari total rata-rata semua atribut yan terdiri dari 133 data.

Berdasarkan hasil dari masing-masing cluster, sehingga dapat disimpulkan bahwa cluster pertama merupakan produk yang sedikit diminati, sehingga persediaan stok dengan jumlah sedikit, cluster kedua merupakan produk yang paling diminati, sehingga persediaan stok dengan jumlah banyak, cluster ketiga merupakan produk yang cukup diminati, sehingga pesediaan stok dengan jumlah sedang

Tahap terakhir pada penelitian ini adalah mengevaluasi hasil clustering yang dilakukan menggunakan algoritme K-Means dan K-Medoids. Seperti yang sudah dijelaskan pada bagian sebelumnya, proses evaluasi menggunakan Davies Bouldin Index. Berikut hasil evaluasi pada dataset Shopee dan Tokopedia menggunakan metode $k$ means dan $k$-medoids yang di proses pada rapidminer yang ditunjukkan pada Gambar 6 . 


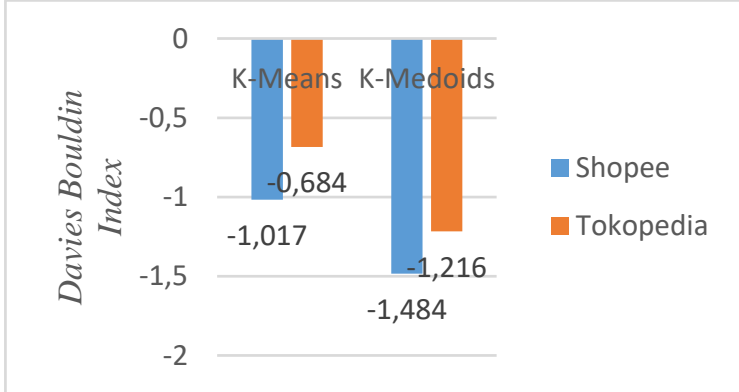

Gambar 6. Perbandingan Evaluasi Menggunakan RapidMiner

Hasil dari proses evaluasi clustering tersebut menghasilkan nilai sebesar $-1,017$ dan $-0,684$ pada $k$-means, sedangkan pada $k$-medoids menghasilkan nilai sebesar -1,484 dan -1,216. Diantara algoritma keduanya $k$-medoids memiliki nilai yang lebih kecil dibandingkan dengan $k$-means, sehingga pada penelitian ini $k$-medoids memiliki performa yang lebih baik dibandingkan $k$-means.

\section{KESIMPULAN}

Teknik clustering telah berhasil diterapkan untuk menganalisis strategi pemasaran, yaitu strategi penambahan stok dan promosi pada sebuah produk buku yang dijual pada toko online Shopee dan Tokopedia. Kelompok yang dihasilkan yaitu sebanyak tiga kategori, kategori banyak, sedang, dan sedikit. Kategori tersebut menggambarkan jumlah buku yang harus disediakan, jika buku masuk pada kategori banyak maka stok yang harus disediakan harus banyak, jika buku masuk pada kategori sedang maka stok yang harus disediakan harus sedang, dan jika jika buku masuk pada kategori sedikit maka stok yang harus disediakan sedikit, karena peminat buku tersbut sedikit. Berbanding terbalik untuk mempromosikan buku, buku yang masuk pada kategori sedikit dan banyak harus mendapatkan perlakuan khusus untuk dipromosikan, agar peminatnya bertambah. Terkait hasil cluster, peneliti menyarankan menggunakan hasil kluster dari algoritme K-Medoids, karena berdasarkan hasil evaluasi, algoritme tersebut lebih baik dibandingkan dengan algoritme K-Means. Penelitian yang dapat dilakukan selanjutnya yaitu dapat menambahkan jumlah dataset yang digunakan, agar dapat menghasilkan pola cluster yang lebih akurat.

\section{REFERENSI}

Databoks. (2019). Berapa Pengguna Media Sosial Indonesia? Retrieved January 3, 2019, from https://databoks.katadata.co.id/datapublish/201 9/02/08/berapa-pengguna-media-sosialindonesia
Fauzansyah. (2017). Implementasi Algoritma KMeans Clustering Untuk Menentukan Arketipe Pembelian Suku Cadang Dan Asesoris Komputer(Studi Kasus Di Toko Laksamana Komputer Dumai). Jurnal Informatika, Manajemen Dan Komputer, 9(1), 26-35.

Millward, S. (2014). Indonesia diproyeksi lampaui 100 juta pengguna smartphone di 2018, keempat di dunia. Retrieved April 19, 2019, from https://id.techinasia.com/jumlahpengguna-smartphone-di-indonesia-2018

Philip, K., \& Amstrong, G. (2012). Prinsip-prinsip Pemasaran (Edisi 1). jakarta: Erlangga.

Prasetyo, E. (2014). Data Mining - Mengolah Data Menjadi Informasi Menggunakan Matlab. Yogyakarta: Andi Offset.

Rahmayani, I. (2015). Indonesia Raksasa Teknologi Digital Asia. Retrieved April 17, 2019, from https://kominfo.go.id/content/detail/6095/indo nesia-raksasa-teknologi-digitalasia/0/sorotan_media

Ramadhani, R. D., \& Ak, D. J. (2017). Evaluasi KMeans dan K-Medoids pada Dataset Kecil. In Seminar nasional Informatika dan Aplikasinya (pp. 20-24). Cimahi.

Setiawan, S. (2018). Pemanfaatan Metode K-Means Dalam Penentuan Persediaan Barang. In Jurnal Penelitian Ilmu Komputer, System Embedded \& Logic (Vol. 6, pp. 41-48). Retrieved from https://www.google.com/url?sa=t\&rct=j\&q=\& esrc $=$ s\&source $=$ web $\& c d=1 \& c a d=r j a \& u a c t=8$ \&ved=2ahUKEwi6r5H_oJPjAhXQZSsKHb9 GA1oQFjAAegQIAxAC\&url=http $\% 3 \mathrm{~A} \% 2 \mathrm{~F} \%$ 2Fjurnal.unismabekasi.ac.id\%2Findex.php $\% 2$ Fpiksel\%2Farticle\%2Fdownload\%2F1398\%2 F1254\%2F\&usg=AOvVaw3IDKYr8-Fg38Uk

\section{PROFIL PENULIS}

Wiga Maulana Baihaqi, lahir di Cilacap, tanggal 2 Agustus 1993. Telah menempuh pendidikan S1 Sistem Informasi di STMIK Amikom Purwokerto pada tahun 2015, dan melanjutkan pendidikan pasca sarjana Teknologi informasi di Universitas Gadjah Mada pada tahun 2015 dan selesai pada tahun 2017.

Kuat Indartono, merupakan dosen Teknik Informatika di Universitas Amikom Purwokerto

Syifaul Banat, lahir di Brebes, tanggal 30 September 1997, Merupakan mahasiswa Sistem Informasi di Universitas Amikom Purwokerto 